\title{
ISLAM DI TENGAH PERDEBATAN FAHAM LIBRALISME, DAN FUNDAMENTALISME, DAN MODERATISME
}

\author{
Ahmad Zaini Dahlan \\ STID Mustafa Ibrahim al-Islahuddiny Kediri \\ Lombok Barat Nusa Tenggara Barat \\ Email: zainidahlan.ahmad@gmail.com
}

\begin{abstract}
ABSTRAK: Pada dasawarsa akhir-akhir ini, berbicara Islam sangat menarik perhatian berbagai kalangan baik dari kalangan Islam sendiri, maupun kalangan non-Islam. Ketertarikan terhadap Islam sebagai sebuah institusi bagi para peneliti, terutama para orientalis, ada yang motivasinya untuk menjatuhkan Islam dari dalam, seperti yang dilakukan oleh Snouck Hourgrounje, maupun ada yang berkeinginan untuk menggali Islam sebagai sebuah peradaban, sebagaimana yang dilakukan oleh H.A.R Gibb, dengan menghasilkan yang spektakuler berjudul Whither Islam menyatakan: Islam is indeed much more then a system of theology, it is complete civilazition (Islam sesungguhnya lebih dari sekedar sebuah agama, ia adalah sebuah peradaban yang sempurna). Sampai saat ini, Islam terus menunjukkan dinamika dan keberagaman eksperesinya. Tema-tema dominan dalam Islam adalah revivalisme Islam. Suatau dampak yang lebih nyata pada kehidupan kaum Muslim dapat disaksikan diberbagai belahan dunia Islam, entah itu berupa pakaian busana muslimah di Negara-negara sekuler seperti Amirika Serikat, atau dalam kehidupan politik kaum Muslim mulai dari Tunisia sampai Mindano. Dalam bidang ekonomi telah diperkenalkan Bank-bank Islam di Negara-negara yang mayoritas penduduknya Muslim seperti Indonesia.
\end{abstract}

Kata kunci: Islam, Faham Liberalisme, Fundamentalisme, dan Moderatisme 


\section{A. Pendahuluan}

Islam kembali ditegaskan secara lebih kuat dalam kehidupan pribadi maupun kehidupan public masyarakat-masyarakat Muslim dengan cara yang ketat dan kadang dramatis yang seringkali disebut sebagai kebangkitan Islam, revivalisme Islam, Liberalisme I.lam, dan Fundamentalisme Islam, serta Moderatisme. ${ }^{1}$ Namun perdebatan dan perjuangan mengatasi persoalan identitas, agama, kebudayaan, dan prilaku tidak hanya di dunia Muslim tetapi juga di Barat. Pada awal abad ke 21 pembedaan yang tegas anatara Islam dan Barat tidak ada lagi. Islam saat ini memang agama Internasional. ${ }^{2}$ Sementara umat Islam di Negaranegara yang mayoritas penduduknya Muslim sedang memperjuangkan peran Islam dalam Negara dan masyarakat, sedangkan komunitas-komunitas Muslim minoritas di Eropa, Ausralia, dan Amerika Serikat bergulat dengan masalah-masalah asimilasi agama dan budaya.

\section{B. Liberalisme Islam}

\section{Pengertian Islam Liberal}

Islam liberal merupakan madzahab dalam pemikiran Islam yang perhatiaanya terletak pada masalah-maslah Islam dan demokrasi, Islam dan pluralisme, Islam dan Negara, Islam dan kesetaraan Gender, Islam dan modernitas, serta Islam dan Hubungan antar Agama.

Berkaitan dengan metodologi berfkir Islam liberal, tampaknya mereka adalah kelompok yang berusaha melakukan interpretasi baru atas doktrin agama Islam. Al-Qur'an dan Sunnah/Hdits, Interpretasi atas sejarah sosial dan konteks sosial. Di sini timbul pertanyaan sebenarnya apa Islam Liberal itu ? untuk menjawab pertanyaan tersebut perlu mengacu sebuah buku yang diedit oleh Charles Kurzman, Liberal Islam: A Sourcebook Oxford University, 1988, karya Leonard Binder, Islamic Liberalism, Chicago University, 1988. ${ }^{3}$

Kurzman mendefinisikan Islam liberal atau liberalisme Islam sebagai kelompok yang secara kontras berbeda dengan Islam adat (customary Islam) dan Islam revival (revivalist Islam). ${ }^{4}$ Costomary Islam adalah sebuah Islam yang ditandai dengan kombinasi kebiasaankebiasaan kederahan dan kebiasaan yang juga dilakukan di seluruh dunia Islam. Misalnya, penghormatan terhadap orang-orang yang dianggap suci, juga petunjuk-petunjuk ritual yang mengekpresikan tradisi-tradisi daerah, seperti menghormati ruh nenek moyang, perayaan tahun baru Islam, dan sebagainya. Revivalist Islam adalah sebuah kelompok Islam yang biasa dikatakan sebagai Fundamentalisme Islam atau Wahabisme. Islam revivalisme menyerang

\footnotetext{
${ }^{1}$ Syamsul Arifin, Studi Islam: Perspektif Sosiologi dan Isu-isu Kontemporer, (Malang: UMM Press, 2009), hlm. 133. Lihat juga Badri Yatim, Sejarah Peradaban Islam, Dirasah Islamiyah II, (Jakarta: Raja Grafindo Persada, 2008), hlm. 2

${ }^{2}$ Sayyed Husein Nasr, Islam, Agama, Sejarah, dan Peradaban, (Surabaya: Risalah Gusti,2003), hlm. 206-207

${ }^{3}$ Zuly Qodir, Islam Liberal: Paradigma Baru Wacana dan Aksi Islam Indonesia, (Yogyakarta: Pustaka Pelajar, 2003), hlm. 71

${ }^{4}$ Charles Kurzman, Liberal Islam: Sourcebook, (Oxford University Press, 1988), Lihat Leonard Binder, Introduction Islamic Liberalism, (Chicago University Press, 1988)
} 
Customary Islam, karena customary Islam dianggap kurang memberi perhatian pada inti doktrin Islam.

Sementara tradisi Islam liberal adalah tradisi Islam yang menghadirkan masa lalu dalam konteks modernitas, dan menyatakan bahwa Islam jika diapahami secara benar maka ia akan sejalan dengan liberalisme Barat. Tentang bentuk-bentuk Islam liberal dapat dibedakan menjadi tiga, yaitu pertama, Liberal Syari'ah, secara eksplsit liberalist Islam didukung oleh Syari'at. Kedua, Silent Syari'at yaitu sikap leberal yang dibiarkan oleh Syariah. Karena Syari'ah boleh diinterpretasikan secara terbuka oleh siapa saja. Ketiga, Interpretated Syari'ah (hukum) Islam sehingga siapa saja bisa melakukannya. Pendek kata, liberal Islam dapat dikategorikan menjadi tiga, Liberal Syari'ah, Silent Syari'ah dan interpretated Syari'ah. ${ }^{5}$

Sementara itu, Leonerd Binder, mengemukakan bahwa bgi kaum muslim liberal, bahasa al-Qur'an sebenarnya merupakan hal yang sederajat dengan hakekat wahyu, namun isi dan peawhyuannya tidak bersifat verbal. ${ }^{6}$ Karena al-Qur'an tidak seacar langsung mengungkapkan makan pewahyuan, maka diperlukan upaya pemahaman yang berbasis katakata, namun bukan hanya terbatas dengan kata-kata, tetapi harus mecari apa yang hendak disampaikan oleh bahasa wahyu tersebut, dari sanalah kemudian akan menemukan akarnya yang paling liberal, ketimbang ketika Islam hanya dipahami lewat ritual simbolik semata.

Dari kedua pendapat tersebut di atas, dapat diambil benang merah bahwa Islam liberal adalah pemikiran Islam yang berupaya menafsirkan al-Qur'an atau teks keagamaan sesuai dengan zaman yang senantiasa terus berkembang yakni dengan menggunakan kebebasan dalam pemikirannya. Hal ini dikarenakan tanpa gelombang kebebasan dalam pemikiran keagamaan sungguh sulit dibayangkan akan terjadi transformasi masyarakat jalur agama. Agama tidak bisa berbicara dengan sendirinya, tetapi harus ditransformasikan dan ditafsirkan oleh umat manusia. Ini sebuah keyakinan yang mestinya tertanam pada semua umat beragama, sehingga agama sebagaimana dituduhkan Karl Marlk sebagai opium.

Untuk itulah, Tuhan mesti dihadirkan kembali ke muka bumi ini, dengan slah cara adalah orang-orang beragama semangat solidaritas sosial berupaya mersespon tantangan-tantangan kemanusiaan, seperti kemiskinan, kebodohan, dan penindasan baik kultural maupun struktural. Transforamasi agama harus dilakukan dengan segera, agar Tuhan tidak dianggap mati lagi oleh pengikut Nietzsche, melainkan memiliki masa depan. Transformasi inilah yang bisa disebut sebagai bentuk riil dari gerakan Islam liberal. Tetapi sebelum mealakukan transforamasi, umat sejatinya telah dengan jelas melakukan kajian-kajian kritis atas fenomena sosial dijadikan sebagai basis analisis untuk kemudian dikerjakan pada tataran praktis. Inilah yang disebut sebagai proses tranformasi pemikiran keagamaan karena faktor liberalisasi pemikiran. Tanapa adanya gerakan pmikiran penulis percaya agama hanya bersifat "membeku" bahkan karena memang telah lama diturunkan kepada umat manusia.

\section{Perinsip-Prinsip Islam Liberal}

\footnotetext{
${ }^{5}$ Zuly, Islam Liberal, hlm. 73

${ }^{6}$ Leonard Binder, Introducion Islamic Liberalism, (Chicago University Press, 1998)
} 
Islam liberal berkeinginan agar Islam sebagai institusi agama relevan secara sosisial dan keagamaan sepanjang waktu dalam menghadapi berbagai perubahan. Atau secara ideal, Islam liberal dipopulerkan agar umat Islam di satu sisi mampu menjadi muslim yang baik, namun di sisi lain mereka mampu menjadi musim yang modearn. Untuk menuju kearh itu maka doktrin atau ajaran Islam ditafsirkan secara kontektual, histories, subtansial, tidak ditafsirkan secara literal atau harfiah. ${ }^{7}$ Hal itulah yang dilakukan oleh kelompok intlektual yang bergabung di Paramadina yang dipimpin oleh Nurcholis Majid dan kelompok Ciputat.

Oleh karena itu, Islam liberal sebenarnya tidak beda dengan gagasan-gagasan Islam yang dikembangkan oleh Nurcholis Majid dan kelompoknya, yaitu kelompok Islam yang tidak setuju dengan pemberlakuan Syari'at Islam secara formal oleh Negara, kelompok yang gentol memperjuangkan skulerisasi, emansipasi wanita, menyamakan agama Islam dengan agama lain atau pluralisme teologis, memperjuangkan demokrasi barat dan sejenisnya. ${ }^{8}$

Islam liberal juga mendewa-dewakan modernitas ala barat, sehingga Islam harus disesuaikan dengan weternisasi kemodernan. ${ }^{9}$ Jika terjadi konflik antara ajaran Islam dan pencapaian moedernitas, maka yang harus dilkukan menurut mereka, bukanlah menolak modernitas, maka yang harus dilkukan menurut mereka, bukanlah menolak modernitas, tetapi menafsirkan kembali ajaran tersebut. Di sinilah inti ajaran dokterin Islam Liberal.

Islam liberal merumuskan tujuan gerakannya ke dalam empat hal. Pertama, memperkokoh landasan demokratisasi lewat penanaman nilai-nilai pluralime, inklusivisme dan humanisme. Kedua, membangun kehidupan keberagaman yang berdasarkan penghormatan atas perbedaan. Ketiga, mendukung dan menyebarkan gagasan keagamaan pluralis, terbuka dan hmanis. Empat, mencegah agar pandangan-pandangan keagamaan yang militan dan prokekerasan tidak menguasai publik. ${ }^{10}$

Untuk lebih mengenal faham liberalisme Islam, perlu menghadirkan para tokohnya dalam tulisan ini. Salah satu tokoh Islam Liberal yang berkeliber dunia adalah Fazlurrahman dari Pakistan yang hijrah ke Canada, dan Muhammad Arkoun dari Aljazair kemudian hijrah ke Prancis. ${ }^{11}$ Serta Nurcholis Madjid dari Indonesia. Ketiga sarjana tersebut secara sepenuhnya menyadari pentingya merumuskan suatu potret diri bagi Islam, sementara pada waktu yang sama menginsafi bahwa hal tersebut harus dilaksanakan berdasarkan pijakan sejati Islam yang dapat diterima kaum muslimin awam sebagai Islami.

Sementara itu Fazlurrahaman, memusatkan perhatiannya pada penciptaan suatu sistem pendidikan yang betul-betul Islami dan sekaligus memadai untuk dunia modern ini. Dalam rancangannya untuk mencapai hal tersebut ia memberi tempat yang sentral kepada penafsiran baru al-Qur'an. Penafsiran baru al-Qur'an harus memandang ajaran al-Qur'an secara

\footnotetext{
7 Ulil Abshor Abdalla dkk, Islam Liberal dan Fundamental: sebuah Pertarungan Wacana, (Yogyakarta: Elsaq Press, 2005), hlm. 136

${ }^{8}$ Harun Nasution, Islam Rasional: Gagasan dan Pemikiran, (Bandung: Mizan, 1998), hlm. 188

${ }^{9}$ Adian Husaini dan Nuim Hidayat, Islam Liberal: Sejarah, Konsepsi, Penyimpangan dan Jawabannya, (Jakarta: Gema Insani, 2002), hlm. 3

${ }^{10}$ lbid, hlm. 8

11 William Montgomery Watt, Fundamentalisme Islam dan Modernitas, taufiq Adnan Amal (pen), (Jakarta: Grafindo Persada, 1997), hlm. 141
} 
menyeluruh, dan tidak memperlakukan ayat-ayat al-Qur'an secara terpilah-pilah. Ia harus didasarkan pada kajian situasi ksejarahan dimana suatu ajaran tertentu harus dirumuskan, dan kemudian bergerak dari sisni kepada suatu pernyataan yang memiliki tujuan-tujuan moral sosial umum yang diperoleh darinya. Tujuan-tujuan inilah yang akan memberi panduan dalam menangani pemasalahan-permsalahan dewassa ini. Penafsiran baru tersebut biasa dikenal dengan sebutan Double Movement. ${ }^{12}$ Sejalan dengan itu, Islam dalam pandangan Fazlur Rahman ${ }^{13}$ sangat menentang ekskluisfisme, absolutisme, dan sikap-sikap lain semacamya. Untuk menunjukkan penyangkalan Islam yang keras terhadap sikap itu, Rahman merujuk pada surat al-Baqarah (2): 113, 111, dan 120. Pada surat 113 dan 111 dinyatakan:

Orang-orang Yahudi berkata, orang-orang Kristen juga berkata, orang-orang Yahudi tidak berada dalam satu kebenaran pun, dan orang-orang Kristen juga berkata, orang-orang Yahudi tidak berada dalam satu kebenaran pn, sedang keduanya membaca kitab yang sama.

Mereka berkata, tidak seorang pun yang masuk surga kecuali mereka yang beragama Yahudi atau Kristen yang demikian itulah angan-angan mereka.

Dua ayat tersebut menunjuk dengan jelas sikap kaum Yahudi dan Nashroni yang sangat ekslusif. Masing-masing menganggap bahwa keselamatan dan kebahagian akhirat hanya milik mereka saja. Karena sikap eksklusif dan absolutisme mereka itu, mereka berupaya dengan segala cara agar umat Islam dan umat yang lain, semuanya harus masuk ke dalam agama mereka masing-masing, sebagaimana diungkapkan dalam ayat 120:

Orang-orang Yahudi dan Kristen tidak akan pernah rela kepadamu (Muhammad) kecuali jika kamu mengikuti agama mereka; katakanlah (pada mereka): yang merupakan petunjuk itu petunjuk dari Allah.

Berdasarkan ketiga ayat tersebut, Rahman menjelaskan bahwa al-Qur'an memberikan jawaban yang tegas terhadap sikap mereka yang ekskulusif melalui pernyataan bahwa petunjuk bukanlah fungsi dari komunitas tertentu, namun dari Allah dan masyarakat yang baik, dan tidak ada satu masyarakat pun yang dapat mengklaim bahwa mereka adalah sebagai satu-satunya komunitas yang dapat petunjuk dan pilihan Allah.

\section{Fundamentalime Islam}

\section{Pengertian Fundamentalisme Islam}

Dewasa ini kita mengenal istilah "fundamentalisme Islam" atau "Islam fundamentalis". Istilah ini cukup populer dalam dunia media massa, baik yang berskala nasional maupun internasional. Istilah "fundamentalisme Islam" atau "Islam fundamentalis" ini banyak dilontarkan oleh kalangan pers terhadap gerakan-gerakan kebangkitan Islam kontemporer semacam Hamas, Hizbullah, Al-Ikhwanul Muslimin, Jemaat Islami, dan Hizbut Tahrir Al-Islamy. Penggunaan istilah fundamentalisme yang 'dituduhkan' oleh media massa

\footnotetext{
12 Fazlur Rahman, Islam dan Modernitas, (Bandung: Pustaka, 1985), hlm. 3, lihat juga dalam Fazlur Rahman, Gelombang Perubahan dalam islam: Studi Fundamentalisme Islam, (Jakarta: Raja Grafindo Perasada, 2001), hlm. 21

13 Abd A'la, Dari Neomodernisme ke Islam Liberal: Jejak Fazlur Rahman dalam Wacana Islam Indonesia, (Jakarta: Paramadina, 2003), hlm.209
} 
terhadap gerakan-gerakan kebangkitan Islam kontemporer tersebut, disamping bertujuan memberikan gambaran yang 'negatif' terhadap berbagai aktivitas mereka, juga bertujuan untuk menjatuhkan 'kredibilitas' mereka di mata dunia.

Pada dasarnya, fundamentalisme Islam bergelora melalui penggunaan bendera jihad untuk memperjuangkan agama. Suatu ideologi yang kerap kali mempunyai fungsi menggugah militansi dan radikalisasi umat. Selanjutnya, fundamentalisme ini diwujudkan dalam konteks pemberlakuan syariat Islam yang dianggap sebagai solusi alternatif terhadap krisis bangsa. Mereka hendak melaksanakan syariat Islam secara kaffah dengan pendekatan tafsir literal atas al-Quran.

\section{A. Pengertian dan Makna Istilah Fundamentalisme Islam}

Istilah fundamentalisme muncul pertama kali di kalangan agama Kristen di Amerika Serikat. Isilah ini pada dasarnya merupakan istilah Inggris kuno kalangan Protestan yang secara khusus diterapkan kepada orang-orang yang berpandangan bahwa al-Kitab harus diterima dan ditafsirkan secara harfiah. ${ }^{14}$

Di kamus besar bahasa Indonesia menyebutkan kata "fundamental" sebagai kata sifat yang memberikan pengertian "bersifat dasar (pokok); mendasar", diambil dari kata "fundament" yang berarti dasar, asas, alas, fondasi ${ }^{15}$. Dengan demikian fundamentalisme dapat diartikan dengan paham yang berusaha untuk memperjuangkan atau menerapkan apa yang dianggap mendasar.

Istilah fundamentalisme pada mulanya juga digunakan untuk menyebut penganut Katholik yang menolak modernitas dan mempertahankan ajaran ortodoksi agamanya, saat ini juga digunakan oleh penganut agama-agama lainnya yang memiliki kemiripan, sehingga ada juga fundamentalisme Islam, Hindu, dan juga Buddha.

\section{B. Lahirnya Gerakan Islam Fundamentalis}

Secara historis, istilah fundamentalisme muncul pertama dan populer di kalangan tradisi Barat-Kristen. Namun demikian, bukan berarti dalam Islam tidak dijumpai istilah atau tindakan yang mirip dengan fundamentalisme yang ada di barat.

Pelacakan historis gerakan fundamentalisme awal dalam Islam bisa dirujukkan kepada gerakan Khawarij, sedangkan representasi gerakan fundamentalisme kontemporer bisa dialamatkan kepada gerakan Wahabi Arab Saudi dan Revolusi Islam $\operatorname{Iran}^{16}$.

\footnotetext{
${ }^{14}$ William Montgomery W., 1997, hlm. 3

${ }^{15}$ Kamus Besar Bahasa Indonesia, 1990, hlm. 245

${ }^{16}$ Azyumardi Azra, 1996, hlm. 107
} 
C. Empat Mazhab Besar Fundamentalisme Islam di Indonesia

Di Indonesia terdapat banyak kelompok atau mazhab yang menganut fundamentalisme. Berikut ini adalah empat mazhab besar fundamentalisme Islam.

\section{Mazhab Ikhwanul Muslimin}

Ikhwanul Muslimin ini menganut ideologi Abduh dan Rasyid Ridha tapi dalam versi yang lebih ekstrim. Penganut mazhab Abduh di Indonesia dalam versi yang lebih soft adalah Muhammadiyah. Maka dari itu mereka agak dekat dengan Muhammadiyah. Dan para mantan DI/TII rata-rata masuk Muhammadiyah. Di Indonesia sendiri aliran ini bermetamorfosis menjadi PKS, KAMMI, dan sejenisnya dan menjadi kelompok fundamentalis terkuat di Indonesia.

Kalau merunut sejarahnya, organisasi ini merupakan salah satu sempalan Negara Islam Indonesia (NII). NII merupakan kelanjutan DI/TII yang kelahirannya di-backing-i Ali Moertopo c.s. Organisasi ini terlihat cukup soft misal jarang melakukan kekerasan fisik, tapi mereka melakukan kekerasan dalam wacana. Dari segi penampilan untuk pria biasa saja tapi rata-rata berjenggot sementara perempuannya berjubah dan berjilbab model lebar dan panjang.

\section{Mazhab Salafi atau Wahabi}

Mereka ini cukup rasis, nyaris semua pucuk pimpinannya selalu orang Arab/ keturunan Arab yang didukung oleh sejumlah dalil mengenai keutamaan Arab. Laskar Jihad dan Majelis Mujahidin Indonesia (MMI) adalah bagian dari mereka, juga teroris bom Bali, Abu Bakar Ba'asyir, Ja'far Umar Thalib, Abdullah Sungkar dan lain-lain adalah orang Arab. Kelompok inilah yang paling radikal.

Kekhususan mereka adalah mereka golongan Arab masaikh. Kebanyakan dari mereka mengikuti jalur al-Irsyad. Mereka memliki dua golongan besar berdasar mazhab ulama acuannya, yaitu kelompok Saudi dan kelompok Kuwait. Walaupun radikal dan berbahaya, kelompok ini sebenarnya cukup lemah karena mereka terlalu radikal sehingga suka berkelahi sendiri. Misal, tradisi mubahallah atau saling melaknat atas nama Allah seringkali dijadikan solusi bagi mereka untuk menyelesaikan perbedaan pendapat/ paham. Dan kebiasaan inilah yang seringkali memicu mereka terpecah jadi fraksi-fraksi kecil. Basis utama mereka di daerah Solo dimana mereka mendirikan banyak pesantren di sana.

\section{Mazhab Hizbut Tahrir}

Mazhab Hizbut Tahrir ini merupakan kelompok underground. Mereka menginginkan khilafah tapi menolak menempuh jalur politik. Konsep ideologi mereka lebih condong soft dengan dasar pemikiran adalah "mengislamkan" masyarakat umum di mana bila tercapai 
maka khilafah akan terbentuk dengan sendirinya. Kelompok kami tidak punya data cukup memadai tentang kelompok ini dan jalurnya dengan organisasi di Indonesia.

\section{Mazhab Habib}

Habib, Sayyed, Syarif adalah julukan/ gelar bagi Klan Keturunan Nabi. Mereka sangat rasis, misal perempuan dari golongan ini dilarang menikah dengan non Sayyid jika tidak maka mereka akan dibunuh. Kelompok formal tertua golongan ini adalah Jamiat Kheir. FPI merupakan bagian dari golongan ini. Doktrin utama kelompok-kelompok ini sama, yaitu klaim kebenaran tunggal. Secara mazhab mereka sebenarnya lebih dekat dengan paham khawarij, paham ekstrim Islam yang pertama kali muncul dalam sejarah, walaupun mereka mengaku pengikut Ahlus Sunnah.

Contoh paling mudah adalah dengan melihat wacana fiqh mereka. Dalam kitab-kitab fiqh standart kaum Aswaja, semua pendapat mereka akan dianggap sebagai pendapat pribadi, misal "berdasar pendapat ulama mazhab syafi'i", atau "berdasar pendapat Imam Hanafi dst", sedangkan di kalangan kelompok ekstrim ini dari yang paling soft sampai paling ekstrim memiliki kecondongan mengklaim pendapatnya sebagai pendapat Islam, atau kehendak Allah dst. Klaim fiqh mereka selalu didahului kata-kata "menurut Islam ....", "berdasarkan ajaran Islam..." dst, dan kelompok mazhab yang gemar menggunakan klaim seperti ini adalah golongan Khawarij. Ini mungkin tidak terlalu bermasalah bila dilihat sekilas tapi klaim seperti inilah yang paling berpengaruh untuk membawa seseorang menjadi ekstrim.

\section{Perinsip-Perinsip Islam}

prinsip-prinsip yang terdapat dalam agama Islam

1. Mudah, tidak memberatkan atau menyulitkan

Firman Allah:

"Allah SWT tidak membebankan kepada kamu, kecuali apa yang bisa kamu lakukan." (Q.S.Al Baqarah (2) : 286)

Contoh :

Apabila kita di dalam melaksanakan shalat tidak dapat berdiri, bisa melaksanakan dengan duduk, dan apabila juga tidak bisa, dapat melaksanankan dengan berbaring.

\section{Keseimbangan antara kepentingan dunia dan akhirat}

Firman Allah yang tercantum di dalam Al Quran pada Surat Al Qashash ayat 77 yang artinya sebagai berikut:

"Dan carilah apa saja yang telah dianugrahkan Allah kepadamu (kebahagiaan) negeri akhirat, janganlah kamu melupakan kebahagiaan dari (kenikmatan) duniawi....."

3. Keselamatan dan Kedamaian 
Sesuai dengan pengertian Islam yang berarti islah atau damai, selamat, aman, maka jelas bahwa ajaran Islam membawa kepada umatnya dan manusia pada umumnya keselamatan dan kedamaian.

\section{Keadilan dan Persamaan}

Adil berarti meletakkan sesuatu hal sesuai pada tempatnya, sesuatu yang benar harus dikatakan benar dan salah harus dikatakan salah, bukan sebaliknya. Dalam Islam tidak mengenal ras atau golongan, atau kasta. Semua dipandang sama, yang membedakan hanya keimanan dan ketaqwaannya.

\section{Tolong Menolong dan Toleransi}

Islam mengajarkan pada umatnya agar saling tolong menolong, sesama manusia dalam kebajikan, dan menghargai satu sama lain. Islam juga mengajarkan pada umatnya tidak boleh memaksakan agama kita kepada orang lain yang berbeda agama. Dalam Surat Al Kafirun Allah menegaskan "Bagimu Agamamu dan bagiku agamaku," demikian Islam mengajarkan tentang toleransi.

\section{Faham Moderatisme}

Dewasa ini dunia Islam disuguhi dengan berbagai macam realitas keislaman: ada kelompok Islam yang diidentifikasikan dengan ekstremis-teroris, ada yang fundamentalis, ada yang moderat (wasath), dan ada pula yang liberal. Sebetulnya, berbeda dalam berislam sudah ada sejak zaman dulu -bahkan pada zaman khulafaur rasyidin dimana ada kelompok khawarij misalnya.

Lalu, model keislaman seperti apa yang sesuai dengan Al-Qur'an? Dan sesuai dengan apa yang diajarkan Nabi Muhammad saw? Jika merujuk Al-Qur'an Surat Al-Baqarah ayat 143 dimana umat Islam dijadikan sebagai umat yang adil (wasath), maka sudah semestinya model Islam yang adil, tengahan, moderat, wasath lah yang sesuai dengan Al-Qur'an dan yang diajarkan Nabi Muhammad saw.

Yang menjadi pertanyaan selanjutnya adalah, model Islam wasath, moderat, adil, dan tengahan itu yang seperti apa? Apa tanda-tanda atau ciri-cirinya? Mengacu dalam buku Moderasi Islam, setidaknya ada enam ciri-ciri bersikap moderat dalam berislam.

Pertama, memahami realitas. Dikemukakan bahwa Islam itu relevan untuk setiap zaman dan waktu (shalih li kulli zaman wa makan). Disebutkan juga bahwa ajaran Islam itu ada yang tetap dan tidak bisa dirubah -seperti shalat lima waktu, dan ada juga yang bisa dirubah karena waktu dan tempat -seperti zakat fitrah dengan beras, gandum, atau sagu tergantung yang menjadi makanan pokok pada masyarakat itu. 
Umat Islam yang bersikap moderat (wasath) adalah mereka yang mampu membaca dan memahami realitas yang ada. Tidak gegabah atau ceroboh. Mempertimbangkan segala sesuatu, termasuk kebaikan dan keburukannya.

Terkait hal ini kita bisa belajar banyak dari Nabi Muhammad saw. Beliau adalah orang pandai dalam membaca realitas. Salah satu contohnya adalah Nabi Muhammad saw. tidak menghancurkan patung-patung yang ada di sekitar Ka'bah selama beliau berdakwah di sana. Beliau sadar tidak memiliki kekuatan untuk melakukannya pada waktu itu. Namun pada saat Fathu Makkah, semua patung dan kemusyrikan di kota Makkah dihancurkan semua.

Kedua, memahami fiqih prioritas. Umat Islam yang bersikap moderat sudah semestinya mampu memahami mana-mana saja ajaran Islam yang wajib, sunnah, mubah, makruh, dan haram. Mana yang fardlu 'ain (kewajiban individual) dan mana yang fardlu kifayah (kewajiban komunal). Di samping memahami mana yang dasar atau pokok (ushul) dan mana yang cabang (furu).

Ketiga, memberikan kemudahan kepada orang lain dalam beragama. Ada istilah bahwa agama itu mudah, tapi jangan dipermudah. Pada saat mengutus Muadz bin Jabal dan Abu Musa al-Asy'ari ke Yaman untuk berdakwah, Nabi Muhammad saw. berpesan agar keduanya memberikan kemudahan dan tidak mempersulit masyarakat setempat.

Cerita lain, pada suatu ketika ada sahabat nabi yang berhubungan badan dengan istrinya pada siang bulan Ramadhan. Lalu sahabat tersebut mendatangi Nabi Muhammad saw. untuk meminta solusi. Nabi Muhammad saw. menyebutkan kalau hukuman dari perbuatan sahabatnya itu adalah memerdekakan budak, puasa dua bulan berturut-turut, atau memberi makan 60 orang fakir miskin.

Ternyata sahabat tadi mengaku tidak mampu untuk menjalankan itu semua karena dia memang miskin dan payah. Seketika sahabat tadi membawa sekeranjang kurma untuk nabi. Kemudian Nabi Muhammad saw. menyuruh sahabatnya itu untuk menyedekahkan kurma kepada orang yang paling miskin. Sahabat tadi menjawab kalau dirinya lah orang yang paling miskin. Lalu Nabi Muhammad saw. memerintahkan sahabat tadi untuk membawa sekeranjang kurma itu dan menyedekahkan kepada keluarganya sebagai kafarat atas perbuatannya, jima' pada siang bulan Ramadhan.

Keempat, memahami teks keagamaan secara komprehensif. Perlu dipahami bahwa satu teks dengan yang lainnya itu saling terkait, terutama teks-teks tentang jihad misalnya. Ini yang biasanya dipahami separuh-separuh, tidak utuh, sehingga jihad hanya diartikan perang saja. Padahal makna jihad sangat beragam sesuai dengan konteksnya. 
Kelima, bersikap toleran. Umat Islam yang bersikap moderat adalah mereka yang bersikap toleran, menghargai pendapat lain yang berbeda -selama pendapat tersebut tidak sampai pada jalur penyimpangan. Karena sesungguhnya perbedaan itu adalah sesuatu yang niscaya. Intinya sikap toleran adalah sikap yang terbuka dan tidak menafikan yang lainnya.

Para sahabat sangat baik sekali mempraktikkan sikap toleran. Misalnya Abu Bakar melaksanakan shalat Tahajjud setelah bangun tidur, sementara Umar bin Khattab tidak tidur dulu saat menjalankan salat Tahajjud. Para ulama terdahulu juga sangat toleran sekali. Imam Syafi'i misalnya. Bahkan, dia sampai berkata: "Kalau pendapatku benar tapi mungkin juga salah. Pendapat orang lain salah tapi mungkin juga benar."

Keenam, memahami sunnatullah dalam penciptaan. Allah menciptakan segal sesuatu melalui proses, meski dalam Al-Qur'an disebutkan kalau Allah mau maka tinggal "kun fayakun." Namun dalam beberapa hal seperti penciptaan langit dan bumi -yang diciptakan dalam waktu enam masa. Pun dalam penciptaan manusia, hewan, dan tumbuhan. Semua ada tahapannya.

\section{E. Mendialektikan Gerakan Isme-Isme Islam Sebuah Kenisccayaan}

A. Latar Belakang

Berbagai macam paham dan isme-isme merebak di masyarakat. Masing-masing paham dan isme-isme itu membawa-bawa nama Islam. Berikut ini adalah penjelasan mengenai apa itu paham dan isme-isme serta perbedaannya dengan Islam.

\section{B. Isme-isme}

\section{NASIONAL-isme}

"Nasionalisme adalah satu PAHAM yang menciptakan dan mempertahankan kedaulatan sebuah negara (dalam bahasa Inggris nation) dengan mewujudkan satu konsep identitas bersama untuk sekelompok manusia yang mempunyai tujuan atau cita-cita yang sama dalam mewujudkan kepentingan nasional"

Nazisme juga merupakan salah satu bentuk nasionalisme. ${ }^{17}$

\section{ISLAM-isme}

"Islamisme (Arab: الإسلام السياسي), juga dikenal dengan Politik Islam, adalah seperangkat IDEOLOGI yang berkeyakinan bahwa Islam harus menjadi pedoman bagi segala segi kehidupan manusia, baik sosial, ekonomi, politik, budaya, serta kehidupan pribadi” Islam-isme BUKAN Islam. ${ }^{18}$

C. Islam

\footnotetext{
17 https://id.m.wikipedia.org/wiki/Nasionalisme

${ }^{18}$ https://id.m.wikipedia.org/wiki/Islamisme
} 
Islam (Arab: الإسلام) adalah agama yang mengimani satu Tuhan, yaitu Allah. Dengan lebih dari satu seperempat miliar orang pengikut di seluruh dunia, menjadikan Islam sebagai agama terbesar kedua di dunia setelah agama Kristen. Islam memiliki arti 'penyerahan', atau penyerahan diri sepenuhnya kepada Tuhan (Arab: الله, Allāh)."

Islam adalah Islam; tidak ada tambahan kata sifat di belakangnya, apapun itu. ${ }^{19}$

D. Berbagai macam '-isme' yang lain

\section{LIBERAL-isme}

"Liberalisme atau Liberal adalah sebuah IDEOLOGI, pandangan filsafat, dan tradisi politik yang didasarkan pada pemahaman bahwa kebebasan dan persamaan hak adalah nilai politik yang utama." 20

\section{SOSIAL-isme}

"Sosialisme atau sosialis adalah sistem sosial dan ekonomi yang ditandai dengan kepemilikan sosial dari alat-alat produksi dan manajemen koperasi ekonomi, serta teori politik dan gerakan yang mengarah pada pembentukan sistem tersebut." 21

\section{F. Mengikis Fanatisme dan Mengembangkan Toleransi}

Memberikan definisi ukhuwah Islamiah bukanlah suatu pekerjaan mudah. Sebabnya, antara lain, istilah ini bukan hanya menyangkut sikap lahiriah, melainkan juga sikap batiniah. Tetapi, paling tidak kita bisa memberikan gambaran tentangnya, sebagaimana Rasulullah Saw (sepanjang yang saya tahu). Rasulullah menggambarkan ukhuwah Islamiah dengan contoh-contoh. Misalnya: "Muslim yang satu dengan yang lainnya seperti suatu bangunan yang saling kuat-menguatkan", atau "semacam satu tubuh."

Sehingga, kalaupun kita ingin menyusun suatu formulasi (bukan definisi) mengenai ukhuwah Islamiah, paling tidak kita bisa berkata bahwa itu adalah: suatu kondisi dinamis yang diakibatkan oleh adanya perasaan senasib dan sepenanggungan.

\section{Prasyarat-Prasyarat Ukhuwah Islamiah}

Prasyarat bagi terwujudnya ukhuwah Islamiah ini adalah, pertama, harus ada husnuzh-zhan, prasangka baik, terhadap semua saudara. Kalau sejak semula Anda punya prasangka buruk, maka segala apa yang dilakukan oleh pihak lain, walaupun itu baik, Anda tafsirkan jelek, sehingga menimbulkan keretakan. Dan, yang kedua, tidak ada satu kelompok pun boleh

\footnotetext{
${ }^{19}$ https://id.m.wikipedia.org/wiki/Islam

${ }^{20}$ https://id.m.wikipedia.org/wiki/Liberalisme
}

${ }^{21}$ https://id.m.wikipedia.org/wiki/Sosialisme 
ISSN : $2088-6829$

Jurnal Al-Irfani STAI Darul Kamal NW Kembang Kerang

Vol. 01, No. 01, Juli 2020

https://journal.staidk.ac.id/index.php/irfani/

memonopoli kebenaran, sebagaimana tidak ada sekelompok pun yang memonopoli kesalahan.

Prasyarat lain, barangkali, adalah pendidikan. Latar belakang pendidikan seseorang mempengaruhi terwujudnya ukhuwah Islamiah. Semakin tinggi pengetahuan seseorang bisa diharapkan semakin tinggi toleransinya. Sebaliknya, semakin rendah pengetahuan seseorang dan latar belakang pendidikannya, semakin besar kemungkinan timbulnya hal-hal yang negatif, khususnya kalau ada yang mengembus-embus dari luar. Di negeri-negeri Islam yang tingkat pendidikannya maju, ukhuwah Islamiah menyangkut kehidupan beragama (bukan politik) lebih kokoh dibanding dengan di negeri-negeri Islam yang tingkat pendidikan masyarakatnya terbelakang. Contohnya di Mesir. Kalau Anda berbicara menyangkut perbedaan pendapat, di Mesir orang tidak akan memaki Anda.

\section{Dugaan Sumber Perbedaan}

Semua umat Islam sepakat bahwa petunjuk pasti yang tidak diragukan — seratus persen, baik dalam redaksi apalagi maknanya-adalah Al-Quran. Tetapi Al-Quran merupakan teks, redaksi-redaksi, kalimat-kalimat. Setiap kalimat bisa menimbulkan interpretasi yang berbedabeda. Namun demikian, ada interpretasi-interpretasi yang bisa pasti penafsirannya disebabkan oleh adanya dukungan argumentasi-argumentasi lain. Satu contoh, Keesaan Tuhan. Tidak seorang pun dari kaum Muslimin, selama dia Muslim, meragukan bahwa Tuhan itu Esa. Itu diistilahkan dengan qath'i, pasti benar. Selain masalah Keesaan Tuhan di atas, semua Muslim yakin bahwa Nabi Muhammad adalah Utusan Tuhan yang terakhir untuk seluruh manusia; bahwa Hari Kemudian itu ada; bahwa Al-Quran itu benar, tidak ada tambahan, tidak ada kekurangannya, dan sebagainya. Tetapi, ada lagi satu jenis redaksi yang memang bisa menimbulkan dua atau lebih penafsiran. Itu diistilahkan dengan "dugaan yang mendekati kebenaran" atau zhanni.

Kita harus tahu bahwa yang qath'i itu sebenarnya sedikit sekali. Setiap redaksi yang kita temui, walaupun ayat Al-Quran, dalam penafsirannya mempunyai kaitan dengan banyak hal. Imam As-Syatibi menyebutkan paling sedikit sepuluh hal. Satu kata saja, bisa menimbulkan perbedaan berkenaan dengan pengertiannya - apakah etimologis, terminologis ataukah pengertian sehari-hari. Sedang dalam hal hadis, perbedaan penilaian mengenai sahihtidaknya, bisa merupakan sumber perbedaan. Apa-apa yang kita namakan qath'i itu, juga diistilahkan dengan sesuatu yang telah diketahui oleh umat Islam secara pasti (adh-dharurah ma'lumun minaddin). Nah, setiap perselisihan menyangkut hal ini bisa mengakibatkan seorang dinilai bukan Muslim. Tetapi, kalau perbedaan itu hanya dalam ruang lingkup zhanni (hal yang bersifat "dugaan keras") ini, tidak menjadikan seorang yang tidak mengakuinya lantas boleh dianggap keluar dari Islam.

Selanjutnya, kita akan masuk ke dalam soal wewenang penafsiran. Pertama sekali, tidak semua orang boleh semaunya menetapkan sesuatu soal sebagai zhanni atau qath'i. Ada 
prasyarat-prasyarat untuk mendapatkan wewenang itu. Dia harus memperhatikan bagaimana kaitannya dengan hadis, bagaimana kaitannya dengan kaidah-kaidah penafsiran yang lain. Ada syarat-syarat yang sebenarnya telah disepakati oleh ulama-ulama menyangkut wewenang penafsir dan batasannya. Untuk bisa menafsirkan teks Al-Quran, seseorang mesti menguasai pengetahuan bahasa. Arab, sejarah Al-Quran, atau Hadis, ditambah pengetahuan mengenai masalah yang ingin ditafsirkan. Sebagaimana, misalnya, seorang dokter yang akan melakukan pembedahan, disyaratkan memenuhi terlebih dahulu persyaratan penguasaan terhadap kemampuan-kemampuan tertentu, begitu juga agama menetapkan syarat-syarat tertentu sebelum seseorang diberi wewenang untuk menafsirkan. Bukan berarti bahwa kemudian orang tidak boleh berijtihad. Sebab setiap orang yang mau dan berusaha untuk itu, insya Allah, ia akan mampu. Bukankah adanya syarat-syarat bagi seorang yang akan membedah, atau adanya syarat-syarat bagi seseorang yang akan membangun satu gedung itu, tidak berarti larangan untuk membangun, atau membedah?

Melakukan penafsiran sekehendak hati ini sebenarnya salah satu penyakit di dunia Islam: setiap orang merasa bahwa Al-Quran diturunkan untuk semua orang, sehingga semua orang merasa punya wewenang untuk memahaminya, walaupun dia tidak mempunyai syarat untuk itu.

\section{Toleransi bagi yang Zhanni}

Perbedaan yang menyangkut hal-hal yang bersifat dugaan, atau zhanni, bisa atau harus ditolerir oleh semua pihak, selama pendapat tersebut memenuhi persyaratan-persyaratan yang disebutkan di atas. Kita tidak diperbolehkan oleh agama berbeda dalam tujuan, tapi dibenarkan berbeda di dalam cara mencapai tujuan. Islam memberikan kelonggaran pada apa yang disebut tanawa'ul ibadah (keragaman cara beribadah). Idealnya memang cara pun sama seperti pada masa Rasulullah hingga Khalifah r.a. Tapi setelah itu kondisinya sudah tak memungkinkan lagi. Meski harus juga diketahui bahwa agama juga memberikan prinsipprinsip pokok yang membatasi cara tersebut. Dalam. Islam, tujuan tak boleh menghalalkan cara. Dalam batas-batas syar'i tersebut, cara memang perlu berubah-ubah dari satu kondisi ke kondisi lainnya yang sesuai dengan kebutuhan. Bahkan, lebih jauh lagi, Al-Quran memberikan kemungkinan - bahkan membolehkan - dua kelompok dari kaum mukminin berperang (Al-Hujurat: 9). Jadi, kedua kelompok sudah berperang (iqtatalu), tapi toh alQuran masih menyebut mereka mukmin (minal-mu'minin). Kemudian, salah satu tujuan pokok agama, dalam kehidupan sosial, adalah menjaga persatuan. Bahkan dalam beberapa ayat Al-Quran, perpecahan itu terkadang dinamai kekufuran seperti, misalnya, penafsiran Muhammad Abduh dan Hasan Al-Banna tentang ayat 105-106 surah Ali 'Imran.

Jadi, Anda boleh mengemukakan perbedaan-perbedaan ini selama tidak menimbulkan perpecahan. Karena itu, perbedaan-perbedaan faham ini sebaiknya dikemukakan di dalam suatu forum yang bisa menolerir perbedaan pendapat ini, misalnya di Perguruan Tinggi; dan jangan di masyarakat awam. Jadi, tolok ukur kita ini adalah persatuan. 
Berkenaan dengan adat dan kultur, seharusnya itu ditolerir. Agama Islam datang tidak untuk membatalkan adat-istiadat kecuali yang jelas-jelas bertentangan dengannya. Sekian banyak adat-istiadat yang berlaku di kalangan kaum musyrikin Makkah dibenarkan oleh Islam. Secara umum kita lihat bahwa ada tiga macam sikap hukum Islam terhadap adat-istiadat masyarakat. Pertama, membatalkan sama sekali. Misalnya, dalam hal adat-istiadat kaum musyrikin menyembah berhala. Kedua, memperbaiki, misalnya, sistem adopsi. Orang-orang musyrikin dulu juga mengangkat anak. Islam membenarkan pengangkatan anak ini, asal tidak sekaligus memiliki hak-hak yang dimiliki oleh anak kandung. Ketiga, membenarkannya sama sekali, dan cukup banyak contoh mengenai hal ini.

\section{Bahaya Mengkafirkan}

Istilah kafir, sepanjang yang saya ketahui,. ada banyak artinya. Al-Quran memakai kalimat kafir itu, paling tidak untuk enam macam arti. Nabi sendiri biasa memberikan arti, yang berbeda-beda, di dalam hadis-hadisnya. Misalnya, suatu kali, Nabi menamakan perbuatan berteriak-teriak dan merobek-robek baju waktu kematian sebagai kafir. Demikian juga seorang yang menuduh atau memfitnah seseorang yang lain sebagai punya keturunan di luar nikah juga dianggap kufur, dan lain sebagainya.

Jika yang hendak dimaksud dengan kafir adalah orang non-Muslim, maka kita tentu harus melihat kriteria yang menentukan bahwa seorang boleh dikatakan non-Muslim. Sehubungan dengan itu, mesti kita ingat bahwa, sebagai makhluk, kita hanya bisa melihat yang lahir, yang nyata. Hati orang kita tidak tahu. Nah, kriteria kita mengatakan ini kafir atau bukan adalah apakah dia mengucapkan dua kalimah syahadat atau tidak. Kalau dia mengucapkan dua kalimah syahadat dan mempercayai hal-hal qath'i, yang tadi sudah kita kemukakan, maka dia bukan kafir. Kalau dia tidak mengucapkan dua kalimah syahadat, atau dia tidak mengakui apa-apa yang telah qath'i, maka kita katakan bahwa dia itu kafir. Apakah dia percaya atau tidak terhadap hal-hal zhanni, itu soal belakang.

Dalam hal menjatuhkan vonis kafir ini, hendaknya kita berhati-hati. Karena akibatnya banyak sekali. Kalau saya berkata bahwa si A kafir, berarti secara langsung saya menceraikan dia dengan istrinya. Sebab seorang Muslim tidak boleh kawin dengan orang kafir. Juga, dengan demikian, saya langsung menganggap bahwa dia tidak boleh mewariskan hartanya. Saya pun telah menganggap bahwa semua amal perbuatannya batal.

Ukhuwah Antar-Mazhab

Berbicara mengenai kelompok-kelompok (firqah-firqah dan mazhab-mazhab) dalam Islam, seperti Ahmadiyah, atau Syi'ah dan sebagainya, pun kita kembali kepada kriteria tadi, apakah kelompok-kelompok ini mengakui hal-hal yang bersifat qath'i. Kalau mereka mengakui, maka mereka termasuk komunitas Muslim. Ahmadiyah misalnya, sejauh mereka tidak menganggap ada nabi sesudah Nabi Muhammad—yang kita fahami sebagai Nabi terakhir yang diutus untuk semua manusia — adalah Muslim. 
Berkenaan dengan Syi'ah, kita mesti sadar bahwa ada banyak submazhab di dalamnya. Dalam hal ini kita mesti berbicara lebih spesifik. Syi'ah Itsna 'Asyariyah, misalnya, fikihnya diajarkan di Al-Azhar dan dianggap sebagai salah satu mazhab yang diakui di dalam kelompok Muslim, walaupun sudah tentu sebagai Sunni kita mempunyai catatan menyangkut pendapat-pendapat mereka. Bahkan, ada sebagian pendapat Syi'ah Itsna 'Asyariyah yang diambil-alih oleh Sunni. Misalnya, termasuk di Indonesia, kita menganggap tidak sah talak yang tidak dipersaksikan oleh dua orang. Dalam mazhab Sunnah, pendapat itu tidak ada.

\section{Semua Golongan Muslim Selamat}

Sehubungan dengan masalah ini, ada suatu Hadis Nabi Saw yang diriwayatkan. oleh AtTurmudzi, dan Abu Daud yang berbunyi:

"Akan berfirqah-firqah umatku menjadi 73 firqah/golongan, semuanya di neraka kecuali satu golongan."

Yang satu golongan ini siapa? Tanya sahabat. Nabi menjawab: "Yang (keyakinan dan pengamalannya) sesuai dengan (keyakinan dan pengamalan)-ku dan sahabat-sahabatku." Mencari yang satu golongan ini, mengakibatkan diskusi dan pembahasan berkepanjangan dari para ulama yang mewakili tiap-tiap golongan yang ada. Masing-masing - baik Sunni, Syi'i, Khawarij, Mu'tazilah dan sebagainya-mengklaim bahwa golongannyalah yang selamat karena mengikuti Nabi, sedang golongan lain tidak selamat. Bahkan kelompokkelompok kecil yang terdapat dalam masing-masing golongan tadi, menyatakan bahwa yang dimaksud oleh Nabi adalah kelompoknya semata-mata. Ada suatu pendapat yang menarik dari Syekh Muhammad Abduh yang agaknya baik untuk direnungkan. Menurut beliau, banyak alternatif yang tergambar dalam benak seseorang yang bersifat obyektif menyangkut pengertian Hadis tersebut, antara lain:

Mungkin satu golongan yang selamat itu, suatu ketika telah pernah ada dan telah punah, sehingga yang ada sekarang kesemuanya termasuk dalam kelompok yang tidak selamat. Mungkin ke-tujuh puluhtiga golongan yang dimaksud itu, belum terbentuk semuanya hingga masa kini.

Mungkin juga satu golongan yang selamat itu, belum lagi terbentuk, atau Kesemua yang ada sekarang ini termasuk dalam kelompok yang selamat itu, karena kesemuanya mengikuti prinsip-prinsip pokok ajaran Islam yang dijelaskan. oleh Nabi secara qath'i.

Muhammad Abduh kemudian menyatakan bahwa: "Yang menggembirakan saya adalah adanya satu riwayat yang menyatakan bahwa 'Yang sesat/binasa hanya satu golongan dari ketujuhpuluhtiga golongan tersebut'." Nah, sekarang, apa kita lantas bisa beranggapan bahwa Syi'ah tidak ikhlas mengikuti Nabi? Khawarij tidak ikhlas mengikuti Nabi? Sunni pun 
keikhlasannya tentu tidak kita ragukan. Yang terjadi hanyalah mereka berbeda interpretasi karena perbedaan hasil ijtihad. Perbedaan pendapat tidak bisa dihindari karena kita sebagai manusia diberi akal. Kita hendaknya jangan terlalu ambisius, sehingga ingin mempersatukan umat dalam seluruh langkah dan tindakan. Biarlah kita ber-fastabiqul khairat, asal tujuan kita sama, insya Allah semua akan berhasil mencapai tujuan. Dengan demikian, adanya golongangolongan ini, asal mereka saling menolerir apa-apa yang boleh ditolerir, malah akan menjadikan masing-masing pihak berpacu untuk menuju sasaran yang sama, sehingga menimbulkan dinamika.

\section{Peran Kepemimpinan}

Selanjutnya, untuk mewujudkan ukhuwah Islamiah, memang dibutuhkan kepemimpinan. Sebab, paling tidak, seorang pemimpin bisa menulari masyarakat dengan sikap ukhuwahnya. Untuk kondisi sekarang ini, idealnya di setiap negara, termasuk di Indonesia, kita punya satu pemimpin. Tetapi kondisi kita sekarang belum memungkinkan. Jadi, sebagai gantinya, bisa ditegakkan kepemimpinan kolektif yang benar-benar mencerminkan semuanya, karena, begitu ada satu yang tidak masuk, akan terdapat ganjalan untuk mewujudkan ukhuwah Islamiah secara menyeluruh.

Mengenai perlu-tidaknya hirarki kepemimpinan untuk kondisi sekarang ini, kita harus lihat apakah hirarki kepemimpinan itu bisa wujud atau tidak. Saya lihat untuk kondisi kita sekarang, belum bisa. Alangkah baiknya, memang, kalau kita memiliki suatu pemimpin umat yang mendapat penghormatan semua pihak dalam ucapan-ucapannya, sikap dan tindakannya, sehingga bisa menghasilkan kepatuhan kepadanya. Karena demikian itulah sebenarnya kepemimpinan yang pernah diterapkan oleh Rasulullah dan sahabat-sahabatnya. Kita sudah bersyukur bahwa sekarang di Indonesia ini kita, dalam beberapa hal, mempunyai semacam satu mufti. Sementara, sekian tahun yang lalu, mengenai masalah awal Ramadhan dan Hari Raya saja kita tidak sepakat. Jadi, sebelum kita sampai ke sana-kepada adanya satu pemimpin umat yang dihormati dan diterima pendapat-pendapatnya oleh semua pihak — kita harapkan adanya wadah yang bersifat kolektif.

Ta'assub, Sumber Perpecahan

Tidak adanya ukhuwah Islamiah bukan diakibatkan oleh adanya mazhab, melainkan oleh kepicikan atau kesempitan pandangan (ta'assub) orang-orang yang menganut mazhab. Jelas, juga bukan karena pemimpin mazhabnya. Kalau kita pelajari sikap keempat imam mazhab (Hanafi, Maliki, Syafi‘i dan Hambali), mereka semua memiliki rasa ukhuwah yang sedemikian besar, sampai masing-masing mereka berkata kepada yang lain, kalau pendapat Anda benar, Anda akan saya ikuti.

Sebagian besar dari penyebab tidak adanya ukhuwah Islamiah adalah tidak adanya husnuzhzhan (prasangka baik) — kita selalu berprasangka buruk (su'uzh-zhan) terhadap pihak lain di kalangan kita. 
Mau tidak mau, harus ada mazhab. Sebab Al-Quran memberikan kesempatan kepada kita untuk berbeda interpretasi, meski Al-Quran juga melarang kita untuk bertengkar. Ada satu contoh menarik berkenaan dengan soal ini. Rasulullah bersabda, seperti yang diriwayatkan Bukhari: "Janganlah seorang pun dari kalian bersembahyang asar kecuali di perkampungan Bani Quraizhah.” Sabda Nabi ini, beliau sampaikan kepada sahabat-sahabatnya yang ketika itu sedang dalam perjalanannya menuju perkampungan Bani Quraizhah. Rupanya, di tengah perjalanan sebelum mereka ke tempat tujuan, waktu ashar telah hampir berlalu. Sehingga sebagian di antara mereka melaksanakan shalat Ashar karena mereka beranggapan bahwa ucapan Nabi Saw tersebut dimaksudkan sebagai perintah untuk bergegas-gegas sehingga dapat sampai di tempat tujuan sebelum waktu Ashar berlalu. Sedang sahabat-sahabat yang lain memahami sabda tersebut sesuai dengan redaksinya "Tidak shalat Ashar kecuali di perkampungan Bani Quraizhah" walaupun waktu Ashar telah berlalu. Perbedaan pendapat akibat pemahaman terhadap jiwa teks dan redaksi teks ini mengakibatkan perbedaan pengamalan. Ternyata kemudian, setelah masing-masing pihak menyampaikan pemahaman dan pengamalannya, Rasul Saw tidak mempersalahkan salah satu pihak; atau, dengan kata lain, membenarkan kedua belah pihak. Dengan demikian Rasulullah memperbolehkan adanya perbedaan interpretasi, dan hal itu tidak perlu menjadikan orang lantas bertengkar.

Pada masa sekarang ini, populer istilah-istilah baru yang saya sama sekali tidak setuju fundamentalis, modernis, ekstremis, dan sebagainya. Pengistilahan-pengistilahan ini sebenarnya sangat merugikan. Semua Muslim, adalah sekaligus fundamentalis dan modernis. Sebab, semua Muslim bertitik tolak dari Al-Quran atau hadis Nabi. Keduanya adalah fundamen kita. Sehingga, yang bertitik tolak dari dan menjadikan keduanya sebagai dasar berpikirnya, adalah fundamentalis. Kemudian, orang-orang yang sama dalam hal-hal yang atasnya mereka diberi wewenang untuk memikirkannya-yakni, yang zhanni-melakukan pembaharuan pemikiran untuk menyesuaikan dengan perkembangan masyarakat, berdasarkan pemahamannya terhadap nash. Orang seperti itu dapat juga dinamai modernis.

Ada juga pengelompokan-pengelompokan seperti Ahlus-Sunnah wal Jama'ah, Syi'ah dan sebagainya. Wallah, semua mengaku Ahlus Sunnah wal Jama'ah. Apalagi kita, di Indonesia, lebih sempit lagi. NU menganggap hanya kelompoknya yang Ahlus-Sunnah wal Jama'ah, di luar NU bukan Ahlus-Sunnah wal Jama'ah. Ya akhi, semua kita Ahlus-Sunnah wal Jama'ah. Semua kita, baik itu Muhammadiyah, NU, maupun Syi'ah.

Sebenarnya, menurut hemat saya, kita sukar mengatakan bahwa umat Islam pernah bersatu, dan sukar juga kita berkata bahwa umat Islam sekarang ini pecah. Sebab sejak dulu sampai sekarang umat Islam selalu bersatu dalam hal-hal yang prinsipil. Tapi kita juga tidak dapat berkata bahwa persatuan itu maujud, kalau persatuan itu mencakup segala sesuatunya. Tuhan sendiri sudah berfirman: 
"Kalau Tuhan menghendaki niscaya dijadikannya kamu satu umat.” (Al-Maidah: 48)

Al-Quran juga menyatakan:

"Jangan kamu seperti menjadi orang-orang yang berkelompok-kelompok dan berselisih." (Ali 'Imran: 105)

Ayat di atas memberikan kesan bahwa adanya kelompok-kelompok itu bisa ditolelir asal jangan berselisih dalam tujuan. Syekh Muhammad Abduh menyatakan bahwa ayat di atas merupakan bukti tentang keharusan adanya kesatuan umat dalam tujuannya, namun ini tidak berarti bahwa kemungkinan perbedaan pendapat atau cara tidak akan timbul. Perbedaan tersebut-menurutnya-masih tetap akan timbul, namun ia tidak akan membahayakan selama kesemuanya mendukung tujuan tadi dan selama kesemuanya memiliki itikad baik.

Mewujudkan Ukhuwah Islamiah

Barangkali langkah pertama yang perlu kita ambil, untuk mewujudkan ukhuwah Islamiah adalah meminta pemimpin-pemimpin masyarakat dan para cendekiawan kita, untuk lebih banyak lagi memahami atau mempelajari ide-ide dari pihak-pihak lain. Mungkin dengan mempelajari ide-ide ini justru bisa ditemukan titik-titik pertemuan. Jangan malah kita tonjolkan perbedaannya. Hal lain yang penting menyangkut toleransi ukhuwah ini adalah, betapapun penilaian kita terhadap kesesatan satu golongan, pada akhirnya kita dianjurkan untuk mengucapkan — sebagai sikap "keluar", bukan sikap ke "dalam” sebagai keyakinanapa yang diperintahkan oleh Allah kepada Rasul-Nya untuk diucapkan kepada kaum musyrikin:

"Kami ataukah tuan-tuan yang berada dalam petunjuk atau dalam kesesatan yang nyata? Katakanlah! Kamu tidak akan dimintai pertanggungjawaban tentang dosa-dosa yang kami perbuat, dan kami pun tidak akan dimintai pertanggungjawaban tentang apa yang kamu perbuat. Katakanlah bahwa Tuhan kita akan menghimpun kita semua, kemudian Dia memberi putusan antara kita dengan benar, dan Dialah Maha Pemberi keputusan lagi Maha Mengetahui." (Saba': 24, 25, 26)

\section{G. Kesimpulan}

Islam liberal merupakan madzahab dalam pemikiran Islam yang perhatiaanya terletak pada masalah-maslah Islam dan demokrasi, Islam dan pluralisme, Islam dan Negara, Islam dan kesetaraan Gender, Islam dan modernitas, serta Islam dan Hubungan antar Agama. Pada dasarnya, fundamentalisme Islam bergelora melalui penggunaan bendera jihad untuk 
memperjuangkan agama. Suatu ideologi yang kerap kali mempunyai fungsi menggugah militansi dan radikalisasi umat. Selanjutnya, fundamentalisme ini diwujudkan dalam konteks pemberlakuan syariat Islam yang dianggap sebagai solusi alternatif terhadap krisis bangsa. Mereka hendak melaksanakan syariat Islam secara kaffah dengan pendekatan tafsir literal atas al-Quran. Umat Islam yang bersikap moderat (wasath) adalah mereka yang mampu membaca dan memahami realitas yang ada. Tidak gegabah atau ceroboh. Mempertimbangkan segala sesuatu, termasuk kebaikan dan keburukannya.

\section{Daftar Pustaka}

Abd A'la, Dari Neomodernisme ke Islam Liberal: Jejak Fazlur Rahman dalam Wacana Islam Indonesia, (Jakarta: Paramadina, 2003)

Adian Husaini dan Nuim Hidayat, Islam Liberal: Sejarah, Konsepsi, Penyimpangan dan Jawabannya, (Jakarta: Gema Insani, 2002)

Badri Yatim, Sejarah Peradaban Islam, Dirasah Islamiyah II, (Jakarta: Raja Grafindo Persada, 2008)

Charles Kurzman, Liberal Islam: Sourcebook, (Oxford University Press, 1988

Leonard Binder, Introduction Islamic Liberalism, (Chicago University Press, 1988)

Fazlur Rahman, Islam dan Modernitas, (Bandung: Pustaka, 1985),

Fazlur Rahman, Gelombang Perubahan dalam islam: Studi Fundamentalisme Islam, (Jakarta: Raja Grafindo Perasada, 2001)

Harun Nasution, Islam Rasional: Gagasan dan Pemikiran, (Bandung: Mizan, 1998)

Leonard Binder, Introducion Islamic Liberalism, (Chicago University Press, 1998)

Sayyed Husein Nasr, Islam, Agama, Sejarah, dan Peradaban, (Surabaya: Risalah Gusti,2003)

Syamsul Arifin, Studi Islam: Perspektif Sosiologi dan Isu-isu Kontemporer, (Malang: UMM Press, 2009)

Ulil Abshor Abdalla dkk, Islam Liberal dan Fundamental: sebuah Pertarungan Wacana, (Yogyakarta: Elsaq Press, 2005)

William Montgomery Watt, Fundamentalisme Islam dan Modernitas, taufiq Adnan Amal (pen), (Jakarta: Grafindo Persada, 1997)

Zuly Qodir, Islam Liberal: Paradigma Baru Wacana dan Aksi Islam Indonesia, (Yogyakarta: Pustaka Pelajar, 2003) 